学術論文

\title{
フレキシブルプリント基板を用いた磁気浮上モータ用巻線の誤差検討
}

\section{Examination of Errors in Windings for Magnetic Levitation Motors with Flexible PCB}

\author{
猪股 諒*1, 栗田 伸幸*1(正員)，岡安 孝*2, Wolfgang Gruber*3
}

Ryo INOMATA, Nobuyuki KURITA (Mem.), Takashi OKAYASU, Wolfgang GRUBER

\begin{abstract}
The magnetic levitation motor has no friction or wear, it can realize high rotation speed with a very long duration. We use flexible PCB technology to improve the copper space factor and manufacturing accuracy of the magnetic levitation motor. We wound a flexible PCB sheet with an air-core coil printed on it around a back-iron to produce two windings pairs. The effects of errors during manufacturing cannot be ignored; it is necessary to anticipate mistakes and improve winding patterns. In this paper, we explained the motor's structure and the structure of the flexible PCB and the error that occurs during the winding roll-up process. We clarified that the most massive error exists in the gap between the back-iron and the first sheets.
\end{abstract}

Keywords: axial-force/torque motor, bearing-less motor, flex-PCB winding.

(2020 年 11 月 30 日受付, 2021 年 2 月 21 日再受付, 2021 年 3 月 25 日再々受付)

\section{1 緒言}

小型冷却ファンの故障の主要因は，ボールベアリン グの久陥である $[1]$ 。一方, 磁気ベアリングは回転体を 非接触支持・回転することができるため摩擦・摩耗が なく, 装置を高寿命化することができる[2]。冷却ファ ンを小型化・高性能化するため, 著者らはアキシャル 方向の支持力とトルクを同時に制御可能な小型磁気浮 上モータとして Axial Force/Torque Motor (AFTM)の開 発に取り組んでいる[3]。本小型磁気浮上モータの巻線 を, より高密度化・小型化するために, フレキシブル プリント基板 (Flex Printed Circuit Board: FPCB) によっ て巻線を製造する技術[4]を応用し, AFTM 用巻線とし て使用する[5]。これまでに, モータのパッシブ磁気ベ アリングの性能を測定した[6]。また，安価に使用でき る一般的な FPCB 製造用材料を用いて，巻線中の銅密 度を向上させるため, いくつかの条件でプロトタイプ 製造し, AFTM 用巻線に適した FPCB 構造を明らかに した[7]。本稿では特に，FPCB を使用した巻線の製造 誤差に関して検討したので報告する。

\footnotetext{
連絡先：猪股 諒, $\bar{\top} 376-0052$ 群馬県桐生市天神町二丁目 1-5-1, 群馬大学理工学部電子情報理工学科, e-mail: t201d013@gunma-u.ac.jp

*1群馬大学 *2 日本シイエムケイ株式会社

*3Johannes Kepler University
}

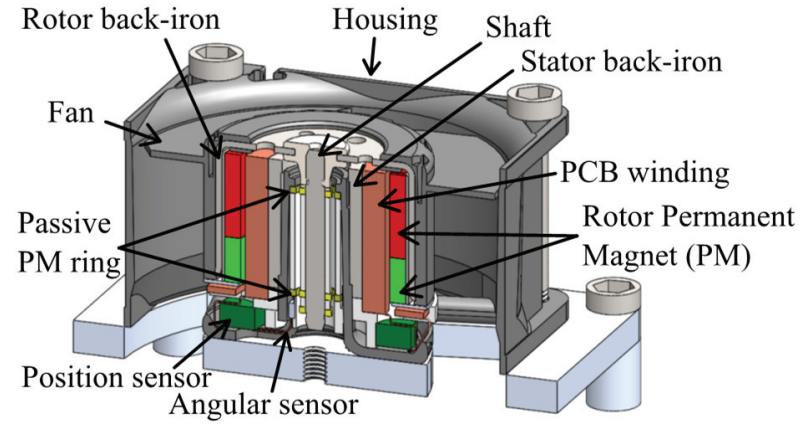

Fig. 1 Cross-section of AFTM fan.

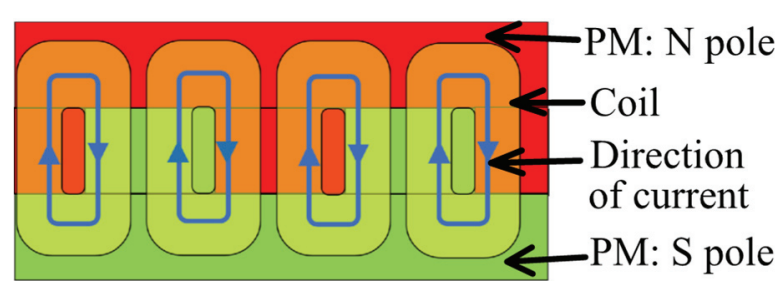

Fig. 2 Arrangement of PMs and air core coils.

\section{$2 \quad$ AFTM ファンの概要}

\subsection{Axial Force/Torque Motor ファン}

AFTM ファンを製造するにあたり，市販の小型ファ ンを改造する。Fig. 1 に AFTM ファンの概要を示す。 ロータは中心にシャフトを有するベル型をしており， ラジアル方向はシャフトとステーターバックアイロン の内側に取り付けたパッシブ磁気ベアリングにより支 持する。浮上・回転力はステーターバックアイロンの 


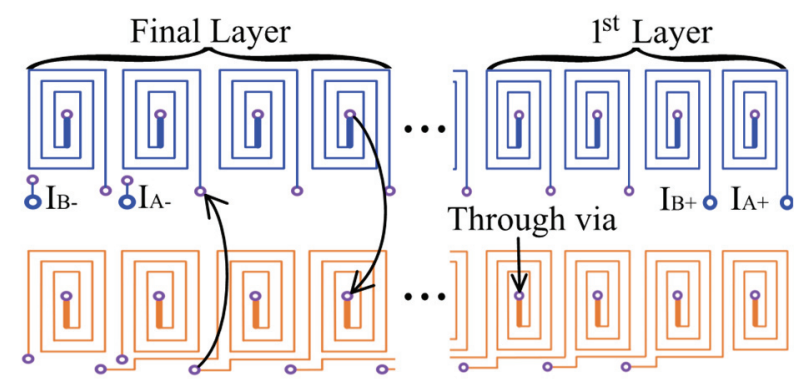

Fig. 3 Schematic diagram of copper wire pattern printed on FPCB windings. (Upper: front, Lower: back)

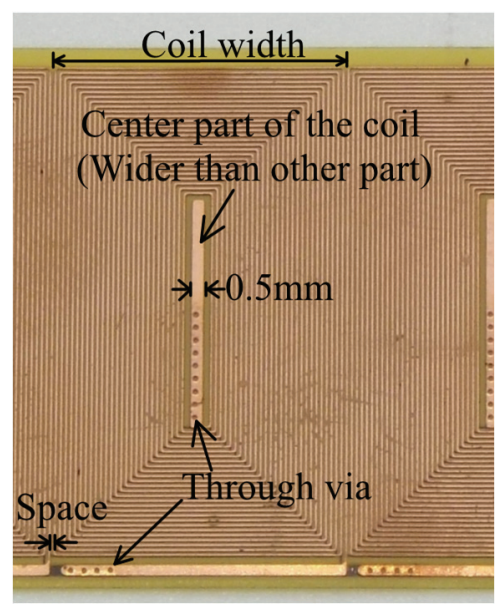

Fig. 4 Photo of the top surface of the manufactured FPCB.

外側に取り付けた巻線とローターバックアイロン内部 の永久磁石により制御する。AFTM の磁石配置を Fig.2 に示す。図面上下方向に 3 つの層に分かれており, 上 部層の永久磁石は $\mathrm{N}$ 極，下部層は $\mathrm{S}$ 極，中間層は $\mathrm{N}-$ S-N-S 極と, 交互に 4 極の磁極を構成する。黄色の角 丸四角形は空芯コイル, 青色の矢印は電流方向を示す。 上下層ではコイルエンドによって浮上力を発生し, 中 間層で回転力を発生することで，浮上力と回転力を同 時に発生することができる。以降では，ステーターバ ックアイロンを単にバックアイロンと呼称する。

\section{$2.2 \mathrm{FPCB}$ 巻線の構造}

巻線に占める銅線の割合を高めるために，高精度の 製造が可能な FPCB を使用する。FPCB 巻線の基本構 造を Fig.3 に示す。上図に表面銅線パターン, 下困に裏 面銅線パターンを示す。青色の丸で示寸入力端子 $I_{A+}$, $I_{B+}$ に接続した銅線は, 表面の空芯コイルを形成した 後, 紫色のリングで示したスルービアを経由して裏面 と接続する。そして，裏面で空芯コイルを形成する。 コイルは 1 つ飛ばしに直列に接続する。Fig. 4 に実際

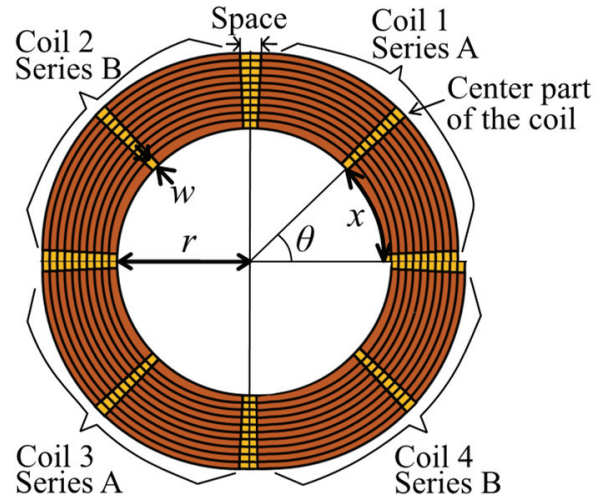

Fig. 5 Schematic of the cross-section of FPCB winding. (Left: 4 air core coils, Right: Parameters)

に製作した FPCB の写真を示す。コイルの中央部は, スルービアを配置するためにほかの部分よりも太くし てある。以降，コイルを巻き上げた時の断面観察にお いては,この部分を基準として角度のずれを検討する。 このような銅線パターンをプリントした長い短冊状の FPCB をバックアイロンに巻き付け, 巻線を形成する。 Fig. 5 に，バックアイロンに反時計回り FPCB を巻き 付けた巻線断面の概念図を示す。AFTM は 2 対のモー タであり，向かい合った巻線を直列に接続する。半径 $r[\mathrm{~mm}]$, シート長 $x[\mathrm{~mm}]$, シート長 $x$ がなす角 $\theta[\mathrm{deg}]$ の間には式(1)の関係がある。

$$
x=2 \pi r \theta / 360
$$

AFTM は 2 対のモータを構成するため， 1 巻きする分 の FPCB シート長に 4 つの空芯コイルパターンをプリ ントする。そのため, コイル 1 (Coil 1, Series A) は，0 $<\boldsymbol{\theta}<90 \mathrm{deg}$, コイル 2(Coil 2, Series B) は, $90<\boldsymbol{\theta}<$ $180 \mathrm{deg}$, コイル 3 (Coil3, Series A) は, $180<\boldsymbol{\theta}<270$ deg, コイル 4(Coil4, Series B) は, $270<\boldsymbol{\theta}<360 \mathrm{deg}$ に存在することが望ましい。また，バックアイロンに FPCB を巻き付ける際，巻き付けるたびにシート厚分 だけ半径が大きくなるため，外側に巻かれるコイルほ どシートの長さ $x$ が長くなる。そこで, 巻き付け回数 を $n$ 巻, $n$ 巻目のシートの半径を $\boldsymbol{r}_{\boldsymbol{n}}$ とし, コイル 1 と コイル 2 の間のスペースが $\theta=90 \mathrm{deg}$ に存在するとき, $n$ 巻目のシート長の $1 / 4$ をコイル幅 $\boldsymbol{x}_{\boldsymbol{n}}$ とすると, 式 (2)と表すことができる。

$$
x_{n}=\pi r_{n} / 2
$$

$x_{n}$ は隣のコイルとの余白 (Space) の長さを含んで いる。半径 $r_{n}$ はシート厚 $w_{n}$ とバックアイロンの半径 


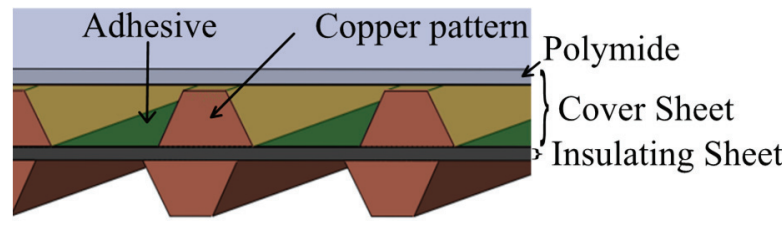

Fig. 6 Schematic of the structure of the FPCB sheet.

$r_{0}$ を用いて，式(3)のように表せる。

$$
r_{n}=\sum_{j=1}^{n} w_{j}+r_{0}
$$

ただし, $n$ は 1 から最外側の巻き付回数 $N$ までの整 数である。 $N$ はシート厚と AFTM ファンにおいて許 容される巻き線部の最大外径寸法から算出すること ができる。幾何的な単純な計算によってコイル幅 $x_{n}$ を決定できるため, 筆者らは FPCB 巻線用回路製 造データを半自動的に生成するプログラムを作成し, 設計コストを大幅に下げることに成功した[8]。

\section{3 誤差を考慮したFPCB 巻線の製造}

\subsection{FPCB 製造過程の誤差}

Fig. 6 に FPCB の断面の概要を示す。絶縁層の表裏 両面に銅線をプリントし，それを接着剤とポリイミド 層で構成されたカバーシートにより覆う。カバーは片 面に施せば巻き付けた際にシート間の絶縁を確保でき るため, FPCB の董側 (図の下側) にはカバーを付けて いない。FPCB シートをバックアイロンに巻き付けて も，接着剤厚や銅線厚の誤差などの様々な要因により 誤差が生じ, コイルには巻き付けごとにばらつきが生 じるため，理想的に整列させることは難しい。そこで 角度誤差を事前に予測し，コイルパターンを修正する 必要がある。角度䛊差の要因には，製造時のシート厚 の誤差，製造時のシート長の誤差，シート巻き付け時 の誤差の 3 つが考えられる。プリントパターンはレー ザー加工であるため精度が高く, 長さ誤差は無視でき る。そこで, 厚さ誤差を評価するために, 目標厚さ 110 $\mu \mathrm{m}$ として設計・製造したシートの厚さ誤差を測定し た。5 枚の FPCB シートを製作し，各コイルの 2 ヶ所 ずつ, 計 10 点で厚さ誤差の程度を観察した。各層厚の 平均を Table 1 に示す。ただし, 絶縁層 (Insulating sheet) は厚さのばらつきが小さく, かつ重要度が低いため測 定していない。そのため, 絶縁層は測定值の平均では なく, FPCB シート総厚 (Whole FPCB sheet) と絶縁層 以外の各層厚との差を表記した。FPCB シート総厚は $112.5 \mu \mathrm{m}$, 標準偏差は $1.8 \mu \mathrm{m}$ であった。FPCB は目標
Table 1 Comparison of specification and cross-section observation results.

\begin{tabular}{|l|r|r|}
\hline & $\begin{array}{c}\text { Specification of } \\
\text { thickness }[\mu \mathrm{m}]\end{array}$ & $\begin{array}{c}\text { Measured average } \\
\text { thickness }[\mu \mathrm{m}]\end{array}$ \\
\hline Polymide & 12 & 14.0 \\
\hline $\mathrm{Cu}(\mathrm{L} 1)$ & 43 & 43.8 \\
\hline $\mathrm{Insulating} \mathrm{sheet}$ & 12 & 11.1 \\
\hline $\mathrm{Cu}(\mathrm{L} 2)$ & 43 & 43.6 \\
\hline Whole FPCB sheet & 110 & 112.5 \\
\hline
\end{tabular}

Table 2 Comparison of target value and cross-section observation results.

\begin{tabular}{|l|r|r|}
\hline & $\begin{array}{c}\text { Target thickness } \\
{[\mu \mathrm{m}]}\end{array}$ & $\begin{array}{c}\text { Measured average } \\
\text { thickness }[\mu \mathrm{m}]\end{array}$ \\
\hline Polymide & 13.5 & 13.1 \\
\hline $\mathrm{Cu}(\mathrm{L} 1)$ & 43 & 44.0 \\
\hline Insulating sheet & 13.5 & 13.6 \\
\hline $\mathrm{Cu}(\mathrm{L} 2)$ & 43 & 42.7 \\
\hline Whole FPCB sheet & 113 & 113.4 \\
\hline
\end{tabular}

值に対して厚さ誤差はプラスに現れやすいこと，同一 シートでもばらつきが生じることが分かった。

\section{2 巻き付け誤差}

前節において, FPCB の厚さは $110 \mu \mathrm{m}$ を目標として もわずかに厚くなったため, 目標厚さを $113 \mu \mathrm{m}$ とす る。そして, 式(2), 式(3)からコイルパターンを計算し, 再度 FPCB を製造した。最終巻き数 $N$ は 31 である。 銅厚の確認のために断面観察を行った。15 ケ所での厚 さの測定結果の平均值を Table 2 に示す。絶縁層の厚さ は Table 1 と同様に, 測定值の平均ではなく, FPCB シ 一トの総厚と絶縁層以外の各層厚との差を表記した。 総厚の平均值は $113.4 \mu \mathrm{m}$ であり, 目標厚よりもさら に $0.4 \mu \mathrm{m}$ 厚くなってしまった。厚さの誤差により, 各 コイルは理想的に存在してほしい位置から，ある角度 だけずれた位置に存在することになる。コイル幅 $x_{n}$, 厚さ誤差を含んだ $n$ 巻き目の半径 $r_{n}$ により, コイル 幅 $x_{n}$ がなす角 $\theta_{r n}$ は式(4)により得られる。

$$
\theta_{r n}=360 x_{n} / 2 \pi r_{n}
$$

なす角 $\theta_{r n}$ は各巻き数 $n$ で個別に計算する。各巻き 数 $n$ におけるなす角 $\theta_{r n}$ を全て加算することでコイル の最終的な配置が求められる。また, 各巻き数 $n$ にお けるコイル中央部の配置も，各巻き数 $n$ におけるなす 角 $\theta_{r n}$ から求められる。求めたコイル中央部の配置は, FPCB シート端と最終巻き $N$ における各コイル中央部 とのなす角であり，巻き数 $n$ が同一であってもコイ ル 1, コイル 2, コイル 3, コイル 4 で異なる。以降, シート端と, 巻き数 $n$ におけるコイル 1 ，コイル 2 , 

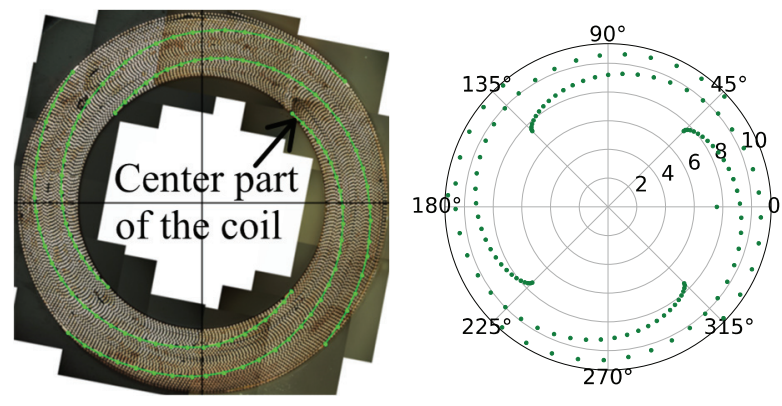

Fig. 7 Cross-section observation results.
Fig. 8 Orbit of the center part at a constant gap of $10.8 \mu \mathrm{m}$.

コイル 3, コイル 4 のコイル中央部とのなす角を巻き 数 $n$ におけるコイル中央部の位置と呼称する。また, $n$ 巻目におけるコイル中央部の位置と, 理想的な場合 である $45 \mathrm{deg}, 135 \mathrm{deg}, 225 \mathrm{deg}, 315 \mathrm{deg}$ との角度差の平 均を，厚さ誤差によって生じるずれの評価指標とし， $n$ 巻目における位置の角度誤差と呼称する。ここで $w_{n}=113.4 \mu \mathrm{m}$ とすると, 式(3), (4)により, 最終巻き $N$ における位置の角度誤差はー6.8 deg になることが分 かった。

製造した FPCB シートを，バックアイロンと同じ半 径のアクリル棒に反時計周りに巻き付け，断面観察を 行った。FPCB の裏面にはカバー層が無いため, バッ クアイロンに直接 FPCB を巻き付けると導通してしま う。そこで，バックアイロンには絶縁性のテープを巻 き, FPCB とバックアイロンを絶縁する必要がある。 断面観察を行った際にも，アクリル棒には厚さ $55 \mu \mathrm{m}$ のポリイミドテープを 1 巻きだけ巻き付けた。プリン トパターンはポリイミドテープの厚さも考慮して設計 した。断面観察結果を Fig. 7 に示す。アクリル棒に巻 き付けた状態の断面観察写真は複数枚の画像となり, 手動でこれらを円状に配置する必要がある。そのため, 合成した画像から半径を測定しても，誤差が大きい。 また, FPCB シートの各巻き付け層の間のギャップは, 拡大画像においても特定することができなかった。そ のため, コイル中央部の角度を測定した。コイルが理 想的な位置にある場合，コイル中央部は Fig. 5 に示す ように，45 deg, $135 \mathrm{deg}, 225 \mathrm{deg}, 315 \mathrm{deg}$ の位置で直線 的に並ぶ。しかし, Fig. 7 では時計周りに大きく湾曲し ている。最終巻き $N$ における位置の角度誤差は, 約 -180 deg であった。これはシートが想定よりも短いこ とを意味する。FPCB シートを製造する際，シートの 長さ方向には誤差がほとんど生じないと考えられる。 そのため，シートの長さが不足するという事は，シー

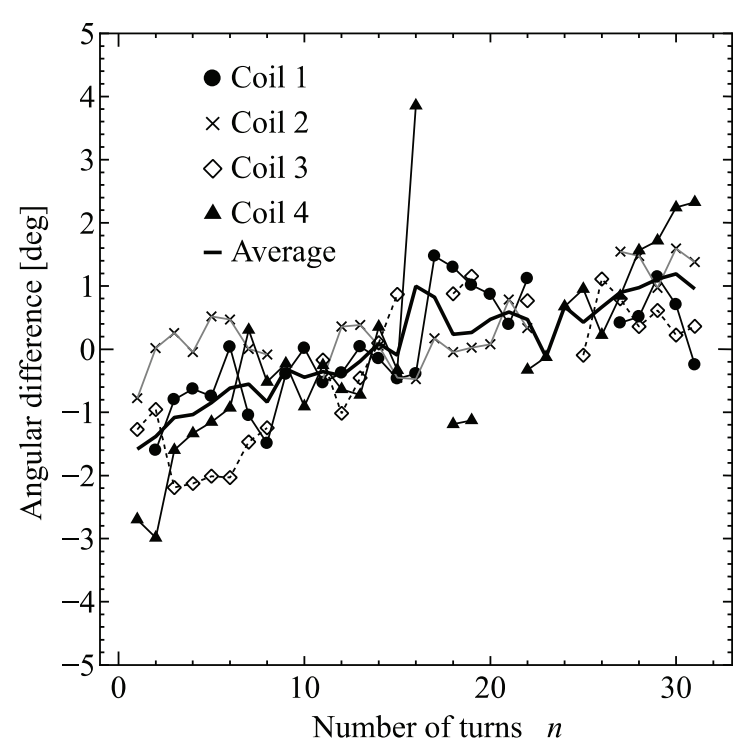

Fig. 9 Angle difference between theoretical value and measured value of center part of the coil.

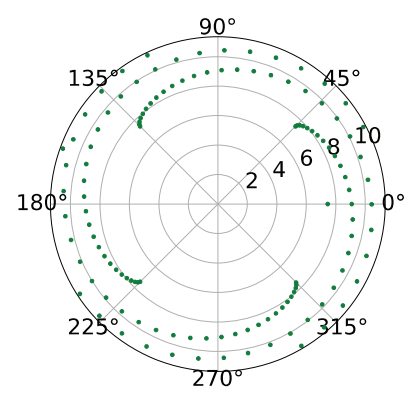

Fig. 10 Calculated orbit of the center part of the coil with proportionally reduced gap.

トを巻き付けた際に，シートとシートの間にわずかに ギャップが生じているためであると考えられる。

そこで，シート間に一定の厚さのギャップが存在 していると仮定し, 式(3)のシート厚 $w_{n}$ にギャップ厚 $w_{g}$ を加え, $w_{n}^{\prime}=w_{n}+w_{g}$ とする。そして,$w_{g}$ を変化 させ, 最終巻き $N$ における位置の角度誤差がー $180 \mathrm{deg}$ となる $w_{g}$ を計算により求めた。結果的に, $w_{g}=10.8 \mu \mathrm{m}$ とした場合, 最終巻き $N$ における位置の 角度誤差はー180 deg となり, コイル中央部の軌跡はFig. 8 となった。図中の第一象限の数值 $(2,4,6,8,10)$ は, 半径を示す。アクリル芯の半径は，バックアイロンと 同じ， $7.5 \mathrm{~mm}$ とした。巻き数 $n \leq 10$ の範囲におい て，コイル中央部の位置が密集している。各巻き数 における観測位置から計算位置を引いた角度差を Fig. 9 に示す。ギャップ $w_{g}$ を一定とすると巻き数 $n \leq 10$ の範囲では角度差が負となり, 巻き数 $n>10$ の範 囲のシートでは角度差が正となることが分かった。つ 


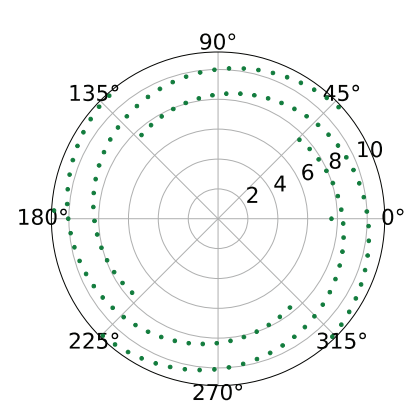

Fig. 11 Calculated orbit of the center part of the coil with high initial gap.

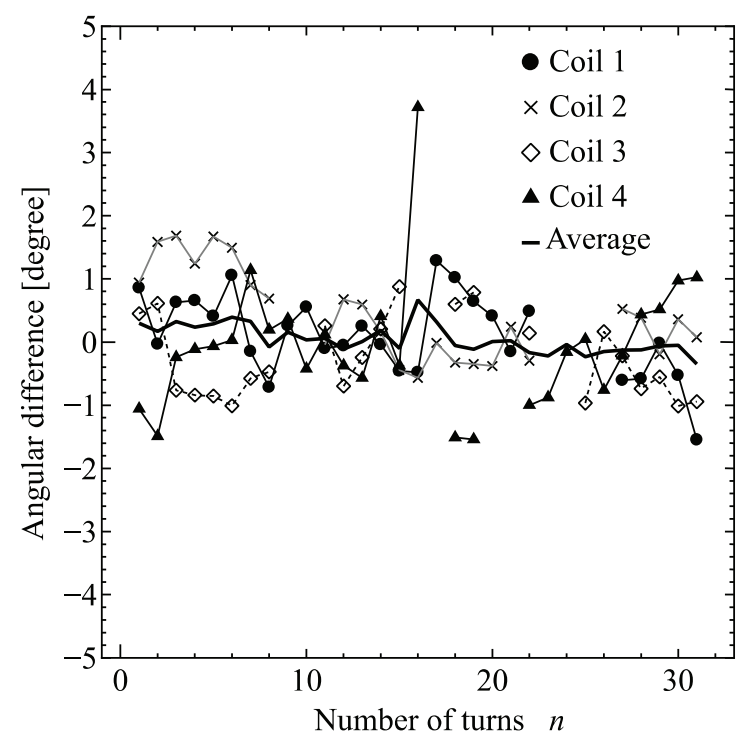

Fig. 12 Angle difference between theoretical value and measured value of center part of the coil.

まり，巻き付けによって生じるシート間のギャップは 一定ではなく, 巻き数 $n \leq 10$ の範囲では大きく, 巻 き数 $n>10$ の範囲では小さいと推定できる。

そこで, ギャップ厚 $w_{g}$ が巻き数 $n$ に比例して小さく なると仮定し, 比例定数を $k_{g}$, 切片を $b$ として, $1 \leq$ $n \leq N$ の範囲で $w_{n}=-k_{g} n+b$ とする。そして, $k_{g}$, $b$ を様々に変化させ, 最終巻き $N$ における位置の角度 誤差が-180 deg となる值を求めた。 $k_{g}=0.0002$, $b=0.1268$ の時の計算結果を Fig. 10 に示寸。ギャップ 一定とした場合と比較すると, わずかに観測值に近づ いたが, 巻き数 $n \leq 10$ の範囲においては依然として 各点が密集しており, 観測值が再現できていないこと が分かる。巻き数 $n \leq 10$ の範囲の值の密集を解消 寸るためには $b$ を大きくする必要があるが，それ では最終巻き $N$ におけるな寸角が再現できない。

観測值のようなコイル配置を再現するためには, $w_{n}$ を不連続とし， $n=1$ における $w_{n}$ を非常に大
きく, $n \geq 2$ における $w_{n}$ は非常に小さくしなけれ ばならないと考えられる。そこで, 巻き数 $n=1$ の時の ギャップ厚を $w_{g 1}$ とし, $n \geq 2$ の時のギャップ厚 $w_{g n}$ を一定とする。そして， $w_{g 1}$ と $w_{g n}$ を様々に変化させ て計算を行った。 $w_{g 1}=145 \mu \mathrm{m}, w_{g n}=0.5 \mu \mathrm{m}$ の時 の計算結果を Fig. 11 に示す。測定值と類似した形状を 再現出できていることが分かる。したがって，アクリ ル棒に FPCB シートを巻き付ける際にポリイミドテー プや瞬間接着剤などによってアクリル棒と FPCB シー トの間に大きなギャップが生じていると推測される。 次に各巻き数における観測位置から計算位置を引いた 角度差を Fig. 12 に示す。全体の平均は $0.06 \mathrm{deg}$ と $0 \mathrm{deg}$ に近く, 標準偏差は $0.81 \mathrm{deg}$ であった。総厚のバラっ きと比較しても小さいため, 観測值を高い精度で再現 できた。

このことから，アクリル棒と 1 巻目の FPCB シート 間のギャップ $w_{g 1}$ 以外には， $0.5 \mu \mathrm{m}$ のギャップが平 均的に存在していると考えられる。ただし, 平均值 は内側では $0 \operatorname{deg}$ 以上であり, 外側では 0 deg 以下にな る傾向がある。したがって，巻き付けによるギャップ は内側では $0.5 \mu \mathrm{m}$ よりもわずかに大きく, 外側では $0.5 \mu \mathrm{m}$ よりもわずかに小さいと推定できる。ギャップ 厚の変化はシートを巻き付ける際の張力の変化や巻き 数に伴う FPCB の曲げ岡性の変化などにより生じてい ると考えられる。

\section{4 結言}

AFTM 用 FPCB 巻線を開発するにあたり, 巻き付け の際に影響する製造誤差を調査した。ポリイミド性の 絶縁テープや接着剤によりアクリル棒と最下層の FPCB シートの間に大きなギャップが生じていたこと が分かった。

今後は, 理想的な巻線を製造するために, 角度誤差 をできる限り小さくなる巻き付け方法を検討する。ま た，FPCB シートをバックアイロンに接着するための 接着剤の厚さを推測する。そして，それを反映したプ リントパターンを設計し, FPCB を製造する。さらに, 完成した巻線を AFTM に組み込んで磁気浮上回転制 御を実施し, 提案手法の有効性を明らかにする。

\section{謝辞}

本研究にあたり, 日本シイエムケイ株式会社 $\mathrm{G}$ ステ イション工場生産技術本部先行開発部先行開発課の皆 様には多大なるご助力を頂きました。厚く御礼申し上 
げます。また, 本研究は JSPS 科研費助成番号 $17 \mathrm{~K} 06223$ および電子回路基板技術振興財団様にご支援を賜りま した。厚く御礼申し上げます。

\section{参考文献}

[1] X. Tian, Cooling Fan Reliability: Failure Criteria, Accelerated Life Testing, Reliability and Maintainability Symposium, 2006. RAMS '06. Annual, 2006.

[2] 一般社団法人電気学会磁気浮上調査専門委員会編, 磁 気浮上技術の原理と応用, 科学情報出版株式会社, 2018.

[3] W. Bauer and W. Amrhein, Electrical Design Considerations for a Bearingless Axial-Force/Torque Motor, IEEE Transactions on Industry Applications, Vol.50, No. 4, pp. 2512-2522, 2014.

[4] B. Dehez, F. Baudart and Y. Perriard, Analysis of a new topology of flexible PCB winding for slotless BLDC machines, 2017 IEEE International Electric Machines and Drives Conference (IEMDC), pp. 1-8, 2017.

[5] N. Kurita, W. Bauer, G. Jungmayr, W. Gruber, and G. Amrhein, Analysis and Design of a Bearigless AxialForce/Torque Motor, Internatonal Power Electronics Conference (IPEC-Niigata 2018 -ECCE Asia), pp. 36403643, 2018.

[6] W. Gruber, W. Bauer, D. Wetsch, B. Klammer and N. Kurita, Implementation of a Bearingless Axial-Force/Torque Motor Fan with Flex-PCB Windings, 2019 IEEE International Electric Machines \& Drives Conference (IEMDC), pp. 179184, 2019.

[7] 猪股, 栗田, 高橋, 岡安, 磁気浮上モータ巻き線用フレ ックス PCB 構成の検討, 第 9 回電気学会杤木・群馬支 所合同研究発表会, 2019.

[8] R. Inomata, N. Kurita, W. Bauer, G. Jungmayer, W. Gruber and T. Okayasu, Auto-Drawing Program of Flex-PCB Windings, TJCAS 2019 in Nikko, 2019. 